\title{
Epidemiology and characterization of Flavescence dorée (FD) and other grapevine yellows
}

\author{
A Caudwell \\ INRA, Station de recherches sur les mycoplasmes et les arbovirus des plantes, BV 1540, 21034 Dijon Cedex, France
}

(Received 10 March 1989; accepted 12 July 1990)

\begin{abstract}
Summary - Since the Flavescence dorée (FD) outbreak in South-Western France during the 1950's, disease on grapevines with similar symptoms have been described throughout the world. From an epidemiological point of view, one can distinguish: Flavescence dorée sensu stricto, transmitted by Scaphoideus littoralis, Mediterranean grapevine yellows, non associated with $S$ littoralis, Bois noir and Vergilbungskrankheit, Subtropical grapevine yellows, North American grapevine yellows. We give a review of the main epidemiological data and the currently available diagnositic methods.
\end{abstract}

vector / differential host / ultramicroscopy / chemotherapy / serology / immunohistochemistry

Résumé - Épidémiologie et caractérisation de la Flavescence dorée et des autres jaunisses de la vigne. Depuis l'épidémie de Flavescence dorée (FD) dans le Sud-Ouest de la France dans les années 50, des maladies de la vigne présentant des symptômes identiques ont été décrites dans de nombreux pays. On peut distinguer du point de vue épidémiologique :

- la FD sensu stricto, transmise par Scaphoideus littoralis, les jaunisses de la vigne méditerranéennes, non associées à $\mathrm{S}$ littoralis, le Bois noir et la Vergilbungskrankheit, les jaunisses de la vigne subtropicales, les jaunisses de la vigne nord-américaines.

Nous proposons une revue des principales données épidémiologiques concernant ces maladies, ainsi que des méthodes de diagnostic actuellement utilisables.

vecteur / hóte différentiel / ultramicroscopie / chimiothérapie / sérologie / immunohistochimie

\section{INTRODUCTION}

The rougeaux (reddening) of black cultivars and the flavescences (yellowing) of the white cultivars have always been known in the countries of long-established viticulture (Ravaz and Verge, 1923; Gärtel, 1965). However, the diversity of the suspected causes and some of the cures obtained showed that several physiological or parasitic disorders were grouped under these denominations including root asphyxia, potassium deficiency of vines planted on alfalfa clearings, and probably also some diseases later known as Bois noir or Vergilbungskrankheit.

For that reason, when Flavescence dorée (FD) appeared in Gascony in the 1950's, it was first linked to the rougeaux and flavescences by
Levadoux (1955) and Branas (1956a,b) and was assumed to be a form of root asphyxia. However, it was this first FD epidemy (Caudwell, 1957) that allowed the characterization of the symptoms specific to the disease and its transmissibility by grafting and by leafhoppers to be established. It was in comparison to $F D$ that Bois noir (BN) and Vergilbungskrankheit (VK) were characterized and that diseases of the same type were found throughout the world.

It is important to establish whether these disorders correspond to different forms of the same disease or if several diseases of the same type appear in response to particular circumstances. This problem is discussed following a review of the current state of the epidemiology and characterization methods. 


\section{EPIDEMIOLOGY OF GRAPEVINE YELLOWS}

Our reviews concerns grapevine yellows, defined as diseases having the same symptoms as $F D$ and associated with mycoplasma-like organisms (MLO) (Caudwell et al, 1971b; Goheen, 1977). This excludes diseases with different symptoms, associated with mycoplasma, found either in cultivation such as Marbour (Milkus, 1974), or by in situ examination such as little leaf (Singh et al, 1975).

The association with MLO is sometimes difficult to establish. It has only been proven in a few cases either directly by observation of the MLO in the host tissues or indirectly by the differential effects of tetracyclines and penicillins.

In order to facilitate the comparison, we can distinguish: FD sensu stricto, transmitted by Scaphoideus littoralis Ball*, Mediterranean grapevine yellows not associated with $S$ littoralis, Bois noir (BN) and Vergilbunskrankheit (VK), Subtropical grapevine yellows, and North American grapevine yellows.

\section{Flavescence dorée sensu stricto}

FD sensu stricto is transmitted by the leafhopper $S$ littoralis (Bonfils and Schvester, 1960; Schvester et al, 1962). At the time of the first outbreak in Gascony in the 1950's, the North American species $S$ littoralis was already widespread in the South of France and possibly in part of Northern Italy and Southern Switzerland (Bonfils and Schvester, 1960; Vidano, 1964; Baggiolini et al, 1968; Osler et al, 1975; Caudwell and Larrue, 1979).

This leafhopper was perfectly adapted to Southern European viticultural areas where summer is long enough for the adults to lay their eggs and the winter cold enough for the diapause to be broken (Caudwell and Larrue, 1979). It was in the regions already colonized by this leafhopper that the epidemics occurred apparently at random, in Gascony (Caudwell, 1957), in Eastern Corsica (Boubals and Caudwell, 1971) and in Pavia, Italy (Belli et al, 1973) in the 1970's and around 1983 in the Languedoc (Heritier, 1983; Caudwell and Larrue, 1986) and Western Corsica, in Veneto and Emilia Romagna, Italy (Credi and Babini, 1984; Belli et al,
1985). This leafhopper was discovered in 1977 in Istria, Yugoslavia and spread to every vineyard of the yugoslavian Karst. However, grapevine yellow was only found in one place near Brda on Pinot blanc (Seljak, 1985; Saric, 1987, personal communication). Foci of $F D$ were recently found in Catalonia, Spain, but $S$ littoralis was not sought for (Valat, 1987, personal communication).

\section{Mediterranean grapevine yellows non associated with $\mathbf{S}$ littoralis}

A disease similar to $F D$ was found by $W B$ Hewitt in Israel in 1963. The diagnosis was confirmed by Gärtel (1965), and the disease was reported more recently in Galilea by Tanne and Nitzany (1973). S littoralis was not found.

A grapevine yellow was described in 1968 in Rumania on cv Regina de Puglia and another in Greece in 1976 but $S$ littoralis was not sought for (Pop, 1968; Rafaila and Costache, 1970; Savin, 1974; Rumbos and Avgelis, 1985).

An FD-like disease was reported in 1986 in Southern Soviet Moldavia. Diseased vines do not seem to survive the winter (Marinescu, 1986, personal communication).

Lastly, a grapevine yellow has been spreading since 1980 near Palermo in Sicily. The disease is epidemic and present throughout the island. Originally found on cv Insolia, it shows, on naturally infected $\mathrm{cv}$ Chardonnay, symptoms identical to $F D$. However, $S$ littoralis has not been detected (Granata, 1985).

\section{Bois noir and Vergilbungskrankheit}

$B N$ and $V K$ have been found in North Eastern France (Burgundy, Jura, Champagne) (Caudwell, 1961) in Western Switzerland (Bovey, 1972), and in Germany (Rhine and Mosel Valley) (Gärtel, 1965; Mendgen, 1971). They display marked similarities but are different from $F D$ : they are found in neighbouring regions with a similar climate. $B N$ and $V K$ appear on isolated plants which show symptoms almost every year. Symptoms are heavy in some plants and slight in others. There is apparently no natural transmission from grapevine to grapevine. This behaviour

\footnotetext{
* $S$ littoralis Ball was first named $S$ titanus Ball by the same author. We acknowledge that the latter had his reasons for changing the name and will keep to the name $S$ littoralis.
} 
suggests an indigenous wild yellow disease transmitted to the grapevine when it is planted in the vicinity. The vector supposedly does not survive on grapevines (Caudwell, 1983). In addition, the range of sensitive cultivars is different. For example Pinot noir, very sensitive to $F D$ is rarely affected by $B N$. $S$ littoralis, the vector of $F D$ is not yet present in most of the regions affected by $B N$ and cannot transmit $B N$ (Caudwell et al, 1971b) or VK (Caudwell and Englert, unpublished results) even experimentally. Therefore, $B N$ and $V K$ are probably related diseases, although different to $F D$.

\section{Subtropical grapevine yellows}

Grapevine yellows have been found in several subtropical regions of the world. Symptoms similar to $F D$ were discovered by Gärtel (1972) in Chile in the Elqui Valley, a place in the Northern desert. Some years later I confirmed the diagnosis but was not able to find any other place in the country affected by the disease (Caudwell, 1980). The graft transmission has not been obtained (Cabrera and Nordenflicht, 1987, personal communication). Similar symptoms were found in Argentina by W B Hewitt in 1980 (personal communication).

The development from 1976 of Australian grapevine yellow (AGY) formerly called the "Rhine Riesling problem" has been very serious. The disease appears very heavy and epidemic like $F D$ in the Northern warm regions and mild, endemic, like $B N$ in the cooler Southern regions. Tetracycline treatments, but not penicillin, prevent symptom expression, a fact which suggests an MLO pathogenicity. However, the disease could not be transmitted by grafting and $S$ littoralis has not been reported (Magarey and Wachtel, 1982, 1985, 1986).

\section{The problem of North American grapevine yellows}

A disease similar to $F D$ was described by Uyemoto (1976), Uyemoto et al (1977), in the Northern New York State and was called the "leaf curl and berry shrivel (LCBS). The disease found on cv de Chaunac (= Seibel 9549) was spreading and possibly vectored by a flying insect. Symptoms were present on the same vines each year until the top of the vines were cut off. Symptoms did not reappear after that time. Some years later similar symptoms were found by Pearson et al (1985) on white Riesling in the same region but they disappeared naturally 2 years later. In 1987 a new spread of the disease was observed in many places. Histological symptoms were identical to those of $F D$. S littoralis was not found although this species originates from the region (Beirne, 1956). No grapevine yellows were found in California, a region where $S$ littoralis is present (Goheen, 1987, personnal communication; Purcell, 1987; personal communication).

We do have some reasons to distinguish $B N$ and $V K$ from $F D$ but we have no means to compare these diseases to the other grapevine yellows. Epidemiology is not a definitive criterion for a pathogenic agent. It can be influenced by climatic or ecological factors. For example, grapevine yellow-affected plants seem to die within a few years in the regions where the winters are cold (Moldavia, New York State). In addition the length of the summer may or may not allow the appearance of the symptoms in the year of inoculation. Lastly, one pathogenic agent could be transmitted by more than one vector insect, according to the region, and insects may differ by the number of annual generations, the host range and the ability or not to survive on grapevines.

Thus, as epidemiology is not a sufficient criterion, it is important to look at the current state of characterization methods available for this type of grape disease.

\section{THE CHARACTERIZATION METHODS OF GRAPEVINE YELLOWS}

Characterization of the yellow disease pathogens (MLO) is not possible by bacteriological means since members of this group could not be cultivated in acellular media. Until now, only virological methods could be used with difficulty, owing the heterogeneity in particle size, shape and density.

\section{Transmission to differential hosts}

Transmission to host plants depends on the availability of transmission means. Mechanical transmission and dodder transmission have been attempted without success (Caudwell et al, 1970a). 


\section{Graft transmission}

Graft transmission of grapevine yellows was obtained in the case of $F D, V K$ and $B N$ but apparently presents difficulties for other grapevine yellows. We must examine the possibilities of grafting with dormant wood, green grafting and tentative heterografting.

In the case of $F D$, we obtained graft transmission by dormant wood only when we used a piece of wood as the diseased partner which was inoculated during the preceding summer and being at this time in a state of winter incubation (Caudwell, 1957, 1964). Graft transmission was also obtained for $V K$ and $B N$, with comparative success, but we do not know the best experimental conditions. Additional difficulties arise for grapevine yellows in other parts of the world; New York State, Australia, Chile, Emilia Roma-gna, where winter graft transmissions have not been obtained. It is generally in hot regions where the symptoms may appear in the year of inoculation. At this time of year, it is likely that no wood, having the $F D$ in a state of winter incubation, can be used as an infectious partner.

Green grafting seems to be a means of overcoming that difficulty. Unfortunately, even though this method was used with some success by $\mathrm{He}-$ vin et al (1978), it gave less success to Credi and Babini (1987) in Italy and none whatsoever in other laboratories, including our own. In order to transmit the Italian grapevine yellow to periwinkle, heterografting was used, but without success (Credi and Babini, 1987).

The conditions for graft transmission of grapevine yellows are not clear, in particular in hot regions where the winter incubation of the $F D$ pathogen in the plant can be rare.

\section{Transmission by leafhopper vectors}

Natural transmission by the vectors is a means for evaluating the sensitivity of a cultivar even when the vector is unknown. The method used in our laboratory (Caudwell, 1965) is that of row couples of 2 different cultivars. The multiplicity of such couples gives rise to a sensitivity scale. We have to take into consideration the severity of the symptoms and the ability of recovery. We then choose the rows during the phase of fast growth of the epidemic. We then used insecticides in order to prevent any reinoculation of the disease. This method is rapid and often saves experimental plots. It is now used by professionals in French regions newly affected by $F D$.
Unfortunately, the method is not useful for comparisons between different grapevine yellows, because the cultivars concerned are often different. It would be necessary for this purpose to establish special plots of differential cultivars. Inoculations can be made either by provoking the conditions of a natural outbreak if the vector is unknown or by closing the vector under gasmantle, as is done for $S$ littoralis. Both methods are laborious and time consuming.

The natural transmission by the vector may also apply to other crops and wild vegetation. To date, no plant other than the grapevine has been found as a host for $F D$ in France, probably because of the specificity of $S$ littoralis for Vitis. However, it is always possible to find another leafhopper able to transmit $F D$ in a given region. This possibility found with Euscelidius variegatus in laboratory conditions (Caudwell et al, 1970b), can arise anywhere at anytime in the field, with the risk of a multiplicity of host plants and of multiple annual generations, making control of the disease difficult. No report of a wild host for grapevine yellows has been made until now anywhere in the world. We must however mention that $B N$ and $V K$ may arise from a natural cycle (wild plant and leafhopper) native to the concerned regions (Caudwell, 1983).

The experimental transmission of $F D$ to herbaceous plants by its natural vector $S$ littoralis was an important step in the study of the disease. The method used was to test the survival capacity of $S$ littoralis on more than 300 herbaceous species. Adequate survival capacity was found in 10 species among which $F D$ could be transmitted to Vicia faba and Chrysanthemum carinatum. The back transmission by $S$ littoralis gave the typical symptoms of $F D$ on Vitis cv BACO $22 \mathrm{~A}$ (Caudwell et al, 1970a). Another leafhopper, $E$ variegatus KBM was found to be able to transmit $F D$ from $V$ faba to $V$ faba and to other species such as various Vicia, Lathyrus, Pisum, Lupinus and Vinca rosea $L$, the classic host for yellow diseases. It is important to note that 15 leafhoppers are needed to infect one Vinca rosea and only 1 to infect $1 \mathrm{~V}$ faba (Caudwell et al, 1970b). Consequently, this species was chosen for the model cycle in the laboratory. The varieties of $V$ faba are not equally sensitive in terms of the amount of plants becoming diseased and rapidity of the response. We have chosen 2 cultivars, Strube and Arla, as particularly sensitive (Caudwell, 1977; Caudwell and Kuszala, 1984).

The infectivity test of $F D$ by injection of $E$ variegatus and revelation on $V$ faba cv Arla was 
used to check the improvements of the extraction and purification methods of the pathogenic agent in order to obtain the first antisera (Caudwell and Kuszala, 1986).

A leafhopper, Euscelidius incisus, able to survive poorly on Vitis was fed on diseased grapevines and then transferred to young healthy periwinkles. One plant out of 31 displayed symptoms 4-5 months after (Credi and Babini, 1987), but the latter were different from those obtained earlier in our laboratory on the same species, with $F D$ transmitted by $S$ littoralis.

\section{The microscopic and ultramicroscopic diagnosis}

In the field of microscopy, one can distinguish between the methods suitable either for showing histological symptoms or for the visualization of the pathogenic agent itself.

\section{Methods suitable for histological symptoms}

The histological symptoms (excessive development of the phloem, lack of lignification, phloem necrosis) were explored at the beginning of the grapevine yellow problem (Caudwell, 1957; Mendgen, 1971), including the use of dyes like phloroglucinol for necrosis (Caudwell, 1957, Pearson et al, 1985) or examination of autofluorescence in UV light (Carle, 1965; Mendgen, 1971; Magarey and Wachtel, 1986). This type of study has been used by Pearson et al (1985) as a complement to the diagnosis.

\section{Visualization of the pathogenic agent}

The visualization methods of the pathogenic agent are more specific and provide information about its nature and localization.

Every optical method in white or UV light specific for DNA is able to reveal the MLO in situ. The Feulgen method which includes acid hydrolysis, releases the cells of the tissues and allows a smear examination of the $F D$ infected $V$ faba (Caudwell and Maizonnier, unpublished data).

The fluorochrome DAPI (4-6 diamidin 2 phenylindol) can be used in thick sections (Seemuller, 1976 ) or in smears after pectinase digestion (Ca- zelles, 1978). For $F D$, the MLO's are easy to find in $V$ faba tissues but difficult in Vitis: they were only found in some cases of vines grown in greenhouses (Caudwell and Fleury, unpublished observations). The fluorochrome Hoeschst 33258, a benzimide compound, may also be useful.

The most commonly used method to detect the pathogenic agent of the yellows is electronmicroscopy (Doi et al, 1967). Several authors have tried to find MLO's in the phloem of grapevines affected by yellows. Mendgen (1971), working on thin sections on Vergilbungskrankheit, did not find any MLO but thread-like viruses which were probably closterovirus associated with the leaf roll disease were found. We found numerous MLO's in FD-infected broad bean or leafhopper but MLO's were only found in grapevine in the single case of a plant artificially inoculated by $S$ littoralis and grown in a greenhouse (Caudwell et al, 1971a). Uyemoto et al (1977) did not find MLO's in more than 2000 thin sections in grapevines showing leaf curl and berries shrivel symptoms. Magarey et al (1987, personal communication) gave some data on MLO detection in a grapevine affected by Australian grapevine yellow. Research in our laboratory has shown the regular in situ detection of MLO in grapevines grown in greenhouses at the beginning of symptom expression (Boudon-Padieu et al, 1987).

\section{Chemotherapy}

The first publication by Doi et al (1967) on MLO etiology of the yellows gave information about temporary symptom remission after tetracycline but not penicillin treatments. It was a confirmation of the pathogenicity of a wall-less procaryote.

Magarey and Wachtel (1986) showed that oxytetracycline but not penicillins are therapeutic for the Australian grapevine yellow. A single trunk injection in winter provided control for 6 successive seasons.

The effect of antibiotics may be dificult to establish in the case of grapevine yellows showing recovery phenomena (Caudwell, 1964). The rate of remission may take into account the amount of natural recovery and reinoculations. Nevertheless, in the conditions where the test is effective, it may be confirmation of MLO etiology. 


\section{Serology}

Serology ought to be an appropriate method for distinguishing different grapevine yellows from each other and also for host and vector tracking.

The model cycle of the FD ( $V$ faba $-E$ variegatus) allowed a rapid infectivity test to be used to check the leafhopper ( $E$ variegatus) or plant ( $V$ faba) extracts and to improve their infectivity. Such extracts, injected into rabbits gave the first sera, either anti-plant $F D$ or anti-leafhopper $F D$.

The new sensitive serological methods, using immunoadsorbents require 1 of the 2 reagents, antigen or antibody or both to be perfectly specific. We were far from the goal, our extracts being poor in MLO yet rich in host proteins. It was however possible, in the case of $F D$ where we had 2 very different hosts (plant and vector) to minimise the non-specific reactions by trapping $F D$ leafhopper antigens with anti-plant $F D$ sera or vice versa. Our non-specific sera then became specific by difference. According to that principle, several methods were possible, bringing into play various immunoadsorbents; the carbon coated grid of the electron microscope for the ISEM method, the plastic supports for the immunoenzymatic methods and the thin sections of diseased tissues (leafhopper, broad bean or grapevine) in immunohistology.

The ISEM method (Derrick, 1973) was performed with the hosts of the model cycle of $F D$, broad bean and $E$ variegatus in crossing the hosts (plant and vector). It was then possible to trap the $F D$-MLO from broad bean with the antileafhopper sera and vice versa. Both reciprocal methods gave the same pictures with the possibility of decoration. It was the first visualization of the MLO in liquid media, not only of $F D$ but of any yellow disease of plant (Caudwell et al, 1982a, b). ISEM gave the first proof of the reality of the MLO serological trapping by antisera. The method was used to improve the purity and the specifity of the antibodies by controlling the amount of non-specific trapping.

The ELISA method first conducted with pooled leafhopper antigens gave poor results. The tests became clearly positive when individual leafhoppers were tested with adsorbed anti $F D$ plant sera. Important fluctuations were detected according to the individual vectors (Boudon-Padieu and Larrue, 1986; Boudon-Padieu et al, 1989). The latter method was used for screening mono- clonal antibodies. We now have 3 efficient monoclonal clones (Schwartz et al, 1989). The test could also be used on individual $S$ littoralis collected in the field in Southern France, showing that the polyclonal antibodies from the model cycle (Vicia faba - Euscelidius variegatus), kept by insect transmission on plants for more than 15 years in the laboratory can be used for the study of the epidemic cycle of the disease in the field.

The reciprocal test on the antigen $V$ faba $F D$ was equally positive but the test on diseased grapevine appears to be difficult. We have seen the difficulty in finding the pathogenic agent in the tissues of diseased grapevine from the field by electronmicroscopy. We encountered the same difficulties with ELISA. It is easier to find MLO's in grapevines grown in greenhouses, and equally to have in that case, positive responses in ELISA (Boudon-Padieu et al, 1987).

According to the same principle of crossing the hosts, it was possible to introduce immunohistological methods. The first results were obtained using immunofluorescence on intact salivary glands of $F D$ leafhoppers, acetone-fixed and saponin-treated in order to make the membrane permeable to the antibodies. The infected glands showed bright green spots inside and outside the glands, in addition to the non-specific yellow-green masses. A good correlation was obtained with the ELISA test made on the rest of the body of the leafhopper (Lherminier et al, 1989a).

The immunogold labelling of the MLO in thin sections of vector's salivary glands was checked by various methods in order to allow penetration of the antibodies according to the fixator and the resin. Good results were obtained with some methacrylate resins and by ultracryotomy. The MLO regularly appear labelled around the membrane (Boudon-Padieu et al, 1987; Lherminier et al, 1989b). We intend to apply the method to the $F D$-infected grapevine and to the study of vector infection.

These serological methods may enable various grapevine yellows to be compared. In fact, their application requires the vector to be known or at least an experimental vector to be used for serum preparation from both diseased vector and herbaceous plant. The method also allows the comparison of every grapevine yellow to $F D$. It is thus possible to check if the same disease is spreading throughout the world or if there are distinct local diseases. 


\section{DISCUSSION AND CONCLUSION}

In summary, we must distinguish between the diagnostic methods for the group of grapevine yellows in general and the diagnostic methods for individual diseases.

In the first case, there is the very constant and characteristic macro- and microscopic symptoms, mainly on the most sensitive cultivars, Baco 22 A, Chardonnay, Aramon or Niellucio. We could add the graft transmissibility, despite difficulties appearing in some cases. An additional criterion is the observation of MLO's in situ either in the grapevine itself (grown in the greenhouse) or in other hosts (herbaceous plants or vectors). FinalIy, under certain conditions, we can test the differential effects of tetracyclines and penicillins.

Among the diagnostic methods used for individual diseases, we retained the use of Pinot noir, sensitive to $F D$ and almost resistant to $B N$ as a differential host. In addition, $S$ littoralis, vector of $F D$ does not transmit $B N$ or VK. Some herbaceous test plants for $F D$ need to be tested for other grapevine yellows. The serological methods open the way for comparing the different grapevine yellows. The current methods require the use of the vector or at least a laboratory vector for serum preparation from both diseased vector and herbaceous plant. At the moment, they open up the possibility for comparing every grapevine yellow to $F D$.

The comparison of the grapevine yellows to $F D$ is in fact the fundamental question. We must establish whether it is the same disease, the $F D$, throughout the world, or whether there are distinct total diseases occurring on grapevine as a consequence of its introduction in new areas. The epidemiology and the characterization methods already described provide some information.

It is tempting for example to compare $F D$ to the so-called Mediterranean grapevine yellows; non associated with $S$ littoralis. In this respect, the outbreak observed in mid and Southern Italy is particularly interesting. It occurred at the same time as the outbreak in the province of Veneto, but $S$ littoralis present in Veneto has not been found in the South. One may ask if another leafhopper has replaced $S$ littoralis, opening the way for the disease to spread to the South, with the risk of multiple annual generations of the vector and of new difficulties in control. Such a relay is theoretically possible because $E$ variegatus is able to transmit the $F D$ from $V$ faba to $V$ faba and to other plants. We have shown that Euscelis plebejus could also fulfil the role (Caudwell et al, $1970 \mathrm{~b})$. If there is one leafhopper able to transmit $F D$ and to survive on Vitis then further contamination could occur. This could also be the case for Greece, Romania and for every Mediterranean and Subtropical grapevine yellow. For the New York State grapevine yellows, additional reasons bring it closer to $F D$ as $S$ littoralis is native to the same region. The pathogen being submitted to an obligatory plant-insect cycle, and with no European insect vector being present during the first stages of the epidemic, the causal agent may also originate from North America. Thus, it is not possible to discard the hypothesis of an identification of that particular grapevine yellow with $F D$ (Caudwell, 1983).

However, equally there are reasons to believe that a wide range of grapevine yellows exist. The first arises from the distinctive characters of $B N$ concerning the sensitivity of Pinot noir and the transmibility by $S$ littoralis. The other concerns the formidable extension of grapevine in new warm regions where it was not traditionally cultivated, a circumstance particularly favourable to a rapid transmission of numerous local yellow disease to the new host Vitis vinifera.

It is the responsibility of international bodies such as the International Council for Study of Virus and Virus Diseases of Grapevine (ICVG) or the Commission of the European Community (CEC) to promote research and diagnosis on grapevine yellows, throughout the world in view of protection, cure, and quarantine measures.

\section{REFERENCES}

Baggiolini M, Canevascini V, Caccia R, Tencalla $Y$, Sobrio $G$ (1968) Présence dans le vignoble du Tessin d'une cicadelle néarctique nouvelle pour la Suisse Scaphoideus littoralis Ball, vecteur possible de la Flavescence dorée. Mitt Schweiz Entomol Ges LX270

Beirne BP (1956) Leafhoppers (Homoptera: Cicadellidae) of Canada and Alaska. Can Entomol (suppl 2) vol 88, $180 p$

Belli G, Fortusini A, Osler R, Amici A (1973) Presenza di una malattia del tipo "Flavescence dorée" in vigneti dell'oltrepo pavese. Riv Pathol Veg (suppl) sér IV, vol 9, 51-56

Belli G, Fortusini A, Rui D (1985) Recent spread of Flavescence dorée and its vector in vineyards of Northern Italy. Phytopathol Mediterr 24, 189-191

Bonfils J, Schvester D (1960) Les cicacelles (Homoptera Auchenorhyncha) dans leurs rapports avec la 
vigne dans le Sud Ouest de la France. Ann Epiphyt 9, 325-336

Boubals D, Caudwell A (1971) Une épidémie de jaunisse dans le vignoble Corse : probablement la Flavescence dorée. Prog Agric Vitic 88, 2-10

Boudon-Padieu E, Larrue J (1986) Diagnostic rapide de la Flavescence dorée de la vigne par le test ELISA sur la cicadelle vectrice. Application à des populations naturelles de Scaphoideus littoralis. Confirmation de la présence de la Flavescence dorée dans les Bouches du Rhône. Prog Agric Vitic 103, 524-526

Boudon-Padieu E, Schwartz Y, Meignoz R, Lherminier J, Larrue J, Caudwell A (1987) Immunoenzymatic detection of the MLO agent of grapevine Flavescence dorée. Correlation with its vizualisation. 9th metting ICVG - September 6-11 Kiryat Anavim Israël, Phytoparasitica 17, 74-75

Boudon-Padieu E, Larrue J, Caudwell A (1989) ELISA and dot-blot detection of Flavescence dorée MLO in individual leaf-hopper vectors during latency and inoculative state. Curr Microbiol 19, 357-364

Bovey R (1972) Présence de la Flavescence dorée en Suisse et relations possibles de cette maladie avec le «Corky bark». Ann Phytopathol $n^{\circ}$ hors série 167-170

Branas J (1956a) La maladie du 22 A. Prog Agric Vitic 45-46, 289-297

Branas J (1956b) La maladie du Chardonnay et les épidémies de Flavescence. Prog Agric Vitic 47-48, 320-325

Carle P (1965) Fluoroscopie des symptômes histologiques de la Flavescence dorée de la vigne. Application à la détection rapide des lésions précoces sur cépage sensible (Baco 22 A). Ann Epiphyt (Paris) 16, n H-Sl, 73-85

Caudwell A (1957) Deux années d'études sur la Flavescence dorée, nouvelle maladie grave et de la vigne. Ann Amélior Plant (Paris) 4, 359-393

Caudwell A (1961) Étude sur la maladie du Bois noir de la vigne : ses rapports avec la Flavescence dorée. Ann Epiphyt 12 (3), 241-262

Caudwell A (1964) Identification d'une nouvelle maladie à virus de la vigne “la Flavescence dorée». Étude des phénomènes de localisation des symptômes et de rétablissement. Ann Epiphyt (Paris) 15 , hors série, $193 p$

Caudwell A (1965) La biologie de la Flavescence dorée et les fondements des mesures préventives. Bull Inf Ing Serv Agr 198, 377-388

Caudwell A (1977) Aspects statistiques des épreuves d'infectivité chez les jaunisses (Yellow's) des plantes et chez les viroses transmises selon le mode persistant. Intérêt de la fève (Vicia faba) comme plante test pour ces épreuves chez les jaunisses. Ann Phytopathol 9 (2), 141-159

Caudwell A (1980) L'amarilliamento de Elqui, nouvelle jaunisse de la vigne au Chili. Proc Congress ICVG, Niagara Falls, Ontario, Sept 8-12, 9-13
Caudwell A (1983) L'origine des jaunisses à mycoplasmes (MLO) des plantes et l'exemple des jaunisses de la vigne. Agronomie 3, 103-111

Caudwell A, Kuszala C (1984) Bioassay techniques to assess plant pathogenicity of mycoplasma-likeorganisms (MLO). Ann Microbiol (Institut Pasteur), 135 A, 255-261

Caudwell A, Kuszala C (1986) Mise au point par l'épreuve d'infectivité d'un milieu d'extraction et d'un milieu de survie, d'une méthode de purification et de conservation au froid de l'agent pathogène (MLO) de la Flavescence dorée. Agronomie 6, 885892

Caudwell A, Larrue J (1979) Examen du problème de la Flavescence dorée dans le cadre de la sélection sanitaire des bois et plants de vigne. Prog Agric Vitic 128-134

Caudwell A, Larrue J (1986) La Flavescence dorée dans le midi de la France et dans le Bas-Rhône. Prog Agric Vitic 103, 22, 517-523

Caudwell A, Kuszala C, Bachelier JC, Larrue J (1970a) Transmission de la Flavescence dorée de la vigne aux plantes herbacées par l'allongement du temps d'utilisation de la cicadelle Scaphoideus littoralis Ball et l'étude de sa survie sur un grand nombre d'espèces végétales. Ann Phytopathol 2 (2), 415-428

Caudwell A, Kuszala C, Larrue J, Bachelier JC (1970b) Transmission de la Flavescence dorée de la fève à la fève par des cicadelles des genres Euscelis et Euscelidius. Intervention possible de ces insectes dans l'épidémiologie du Bois noir en Bourgogne. Congrès ICVG, Colmar, 15-18 juin 1970; Ann Phytopathol $n^{\circ}$ hors série, 1972, 181-189

Caudwell A, Gianotti J, Kuszala C, Larrue J (1971a) Étude du rôle de particules de type «mycoplasme» dans l'étiologie de la Flavescence dorée de la vigne. Examen cytologique des plantes malades et des cicadelles infectieuses. Ann Phytopathol 3 (1), 107-123

Caudwell A, Larrue J, Kuszala C, Bachelier JC (1971b) Pluralité des jaunisses de la vigne. Ann Phytopathol 3 (1), 95-105

Caudwell A, Meignoz R, Kuszala C, Schneider C, Larrue J, Fleury A, Boudon E (1982a) Purification immunologique et observation ultramicroscopique en milieu liquide de l'agent pathogène (MLO) d'une jaunisse végétale, la Flavescence dorée de la vigne. CR Acad Agric Fr 24 février, 407-415

Caudwell A, Meignoz R, Kuszala C, Schneider C, Larrue J, Fleury A, Boudon E (1982b). Purification sérologique et visualisation au microscope électronique de l'agent pathogène (MLO) de la Flavescence dorée de la vigne dans les extraits de vecteurs infectieux et dans les extraits de plantes malades. CR Soc Biol 176, 723-729

Cazelles O (1978) Mise en évidence par fluorescence des mycoplasmes dans les tubes criblés intacts isolés des plantes infectées. Phytopathology $Z$ 91, 314-319 
Credi R, Babini AR (1984) Casi epidemici di giallume della vite in Emilia-Romagna. Vignevini XI, 35-39

Credi R, Babini AR (1987) Attempted transmission of the pathogen causing a grapevine yellows disease in Italy. 7th Cong Mediterr Phytopathol union Granada, Spain

Derrick KS (1973) Quantitative assay for plant viruses using serologically specific electron microscopy. Virology 56, 652-653

Doi Y, Teranaka M, Yora K, Asuyaam H (1967) Mycoplasma or PLT group like microorganisms found in the phloem elements of plants infected with mulberry dwarf, potato witches broom, aster yellows, or Paulownia witches broom. Ann Phytopathol Soc Jpn 33, 259-266

Gaertel W (1965) Untersuchungen über das auftreten und das Verhalten der Flavescence dorée in den Weinbaugebieten an Mosel und Rhein. Weinberg Keller 12, 347-376

Gaertel W (1972) Enfermedades y plagas de la viticultura chilena II parte. Univ Catol Chile Fac Agron Mimeograf $33 \mathrm{pp}$

Goheen AC (1977) Virus and virus-like diseases of grapes. Hortscience 12, 465-469

Granata G (1985) Epidemic yellows in vineyards of CV Inzolia in Sicily. Phytopathol Mediterr 24, 79-81

Heritier J (1983) Présence probable de la Flavescence dorée dans l'Aude. Prog Agric Vitic 102, 23, 569573

Hevin M, Moutous G, Fos A, Rives M (1978) La transmission de la Flavescence dorée par la greffe en vert est facile et suggère que cette maladie est distincte du Corky bark. Proc 6th Conf (ICVG); Monografias INIA 18, 227-229

Levadoux $L$ (1955) Rapport sur l'état sanitaire et la sélection du Baco 22 A. Agriculture 172, 257-259

Lherminier J, Terwisscha Van Scheltinga T, BoudonPadieu E, Caudwell A (1989a) Rapid immunfluorescent detection of the grapevine Flavescence dorée mycoplasma-like organism in the salivary glands of the leafhopper Euscelidius variegatus KBM. J Phytopathol 125, 353-360

Lherminier J, Prensier G, Boudon-Padieu E, Caudwell A (1989b) Immunolabeling of grapevine flavescence dorée MLO in the Salivary glands of Euscelidius variegatus $\mathrm{KBM}$, a light and electron microscopy study. J Histochem Cytochem 38, 79-89

Magarey PA, Wachtel MF (1982) The Rhine Riesling problem recent findings. Australian Grapegrower and Winemaker, April 1982, 78-80

Magarey PA, Wachtel MF (1985) A review of the present status of Australian grapevine yellows. $\mathrm{Ag}$ ric Record (S Aust) 12, (17), 12-18

Magarey PA, Wachtel MF (1986) Australian grapevine yellows. Int J Trop Plant Dis 4, 1-14

Mendgen K (1971) Untersuchungen über eine Vergilbungskrankheit der Reben an Rhein, Mosel und Saar. Weinberg Keller 8/9, 345-431
Milkus BN (1974) Mycoplasma or chlamydiae-like bodies in grape affected by Marbour. Acta Phytopathol Acad Sci Hung 9, 385-388

Osler R, Fortusini A, Belli G (1975) Presenza di Scaphoideus littoralis in vigneti dell oltrepo pavese affeti da una malattia del tipo Flavescence dorée. Inf Fitopatol 6, XXV 13-15

Pearson RC, Pool RM, Gonsalves D, Coffinet MC (1985) Occurence of Flavescence dorée-like symptoms on "white Riesling" grapevines in New York, USA. Phytopathol Mediterr 24, 82-87

Pop I (1968) Cercetari asupra virusurilor si virozelor vitei de vie in Romania. An Inst Cercet Prot Plant 6, 157-164

Rafaila C, Costache M (1970) Ingalbenirea aure of boala noua a vitei de vie in Romania. An Inst Cercert Prot Plant 151-156

Ravaz L, Verge G (1923) Le rougeau. Roumegous et Dehan, Montpellier, $37 \mathrm{p}$

Rumbos I C, Avgelis AD (1985) Natural spread, importance and distribution of yellows, stem pitting and enation disease of grapevine in some viticultural areas of Greece. Phytopathol Mediterr 24, 7378

Savin CH (1974) Comportarea vitelor atacate de Ingalbenirea auri in conditute de la valea calugareasca. An Inst Cercet Vitic Vinicatie, V, 473-486

Schvester D, Carle P, Moutous G (1962) Sur la transmission de la Flavescence dorée des vignes par une cicadelle. CR Acad Agric 47, 1021-1024

Schwartz Y, Boudon-Padieu E, Grange J, Meignoz R, Caudwell A (1989) Obtention d'anticorps monoclonaux spécifiques de l'agent pathogène de type mycoplasme (MLO) de la Flavescence dorée de la vigne. Annales de I'Institut Pasteur. Res Microbiol $140,311-324$

Seemuller E (1976) Fluoreszenzoptischer Direktnachweis von Mykoplasmaähnlichen Organismen in Phloem pear decline und triebsuchtkranker bäume. Phytopathol Z 85, 368-372

Seljak G (1985) Scaphoideus titanus Ball/S littoralis Ball/u Primorskom vinogradarskom rajonu zapadne. Slovenije $G$

Singh SJ, Sastry KS, Sastry KSM (1975) "Little leaf" disease of grapevine from India. Curr Sci (Bangalore) 44, 26-28. Glasnik Zastite Bilja 2, 33-37

Tanne E, Mitzany FE (1973) Virus diseases of grapevine in Israel. Vitis 12(3), 222-225

Uyemoto JK (1976) A new disease affecting the grapevine variety De Chaunac. Proc Am Phytopathol Soc 1, 146 (abstr)

Uyemoto JK, Cummins JR, Abawi GS (1977) Virus and virus-like diseases affecting grapevines in New York vineyards. Am J Enol Vitic 28, 131-136

Vidano C (1964) Scoperta in Italia dello Scaphoideus littoralis Ball, cicalina americana collegata alla Flavescence dorée della vite. Ital Agric 101, 10311049 